\title{
Cost Analysis of Clinical Compounding in Saudi Arabia: Excipients and Vehicles of Pediatric Formulations
}

\author{
Yousef Ahmed Alomi* ${ }^{*}$, \\ General Administration of Pharmaceuti- \\ cal Care, Ministry of Health, Riyadh, Saudi \\ Arabia. \\ Malika Alhada, Head, Pharmacy \\ Services, Alyamma Hopsital, Ministry of \\ Health, Riyadh, Saudi Arabia. \\ Faiz A. Bahadig, Informatics \\ Pharmacist, Pharmaceutical Care Depart- \\ ment, King Abdul-Aziz Medical, City-WR- \\ Jeddah, Ministry of National Guard, Saudi \\ Arabia. \\ Mona Lubbad, Former Head, \\ Extemporaneous Preparation Unit, Phar- \\ macy services, Alyamma Hopsital, Ministry \\ of Health, Riyadh, Saudi Arabia. \\ Ebtesam Nazal, Head, Extem- \\ poraneous Preparation Unit, Pharmacy \\ Services, Alyamma Hopsital, Ministry of \\ Health, Riyadh, Saudi Arabia.

\section{Correspondence:} \\ Dr. Yousef Ahmed Alomi, The Former \\ General Manager of General Administra- \\ tion of Pharmaceutical Care, Former Head, \\ National Clinical pharmacy and pharmacy \\ practice, Former Head, Pharmacy R\&D \\ Administration, Ministry of Health, P.O.BOX \\ 100, Riyadh-11392, Saudi Arabia.
}

Phone no: +966504417712

E-mail:yalomi@gmail.com
Received: 16-11-2018;

Accepted: 22-04-2019

Copyright: () the author(s), publisher and licensee International Journal of Pharmacology and Clinical Sciences. This is an open-access article distributed under the terms of the Creative Commons Attribution Non-Commercial License, which permits unrestricted non-commercial use, distribution, and reproduction in any medium, provided the original work is properly cited.

This is an open access article distributed under the terms of the Creative Commons Attribution-NonCommercial-ShareAlike 4.0 License

Access this article online

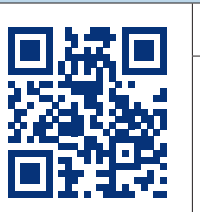

www.ijpcs.net

DOI:

10.5530/ijpcs.2019.8.43

\begin{abstract}
Objectives: To explore cost analysis of excipients of pediatric formulations in Saudi Arabia. Methods: It is a retrospective cost analysis of pediatric formulations at 300-beds pediatrics and maternity hospital in Riyadh city, Saudi Arabia. The pharmacy section received the specific formulation from physician then the expert pharmacist applied the international standard of clinical compounding through by providing to healthcare staff over eight hours per days for five days per a week. The pediatric formulations consisted selected excipients of pediatric formulations. The analysis of the cost included the variable expenses included personal cost, material and supply cost. Fixed costs including direct costs, non-salary cost and overhead cost. The cost was derived from the Ministry of Health information database. All cost was used US dollar currency. The study analyzed the cost of excipients of pediatric formulations through the Microsoft Excel sheet version $10^{\text {th }}$. Results: The estimated average total standard cost of pediatric formulations per hour was (53.82 USD and consisted of $58.58 \%(31.53$ USD) for personal cost, $25.14 \%$ (13.53 USD) for overhead cost, 3.34\% (1.8 USD) for material and supply cost, $12.93 \%$ (6.96 USD) for non-salary cost. The average estimated cost of Simple Syrup per each preparation was (1.974USD). The total annual cost of simple syrup was (426.38 USD). The average estimated cost of methyl cellulose $1 \%$ plus simple syrup per each preparation was (3.721USD). The total annual cost of methyl cellulose $1 \%$ was (759.1USD). The average estimated cost of methyl cellulose $1 \%$ per each preparation was (2.5 USD). The total annual cost of methyl cellulose $1 \%$ was (584.8 USD). The average estimated cost of methyl cellulose $2 \%$ per each preparation was (3.655 USD). The total annual cost of Methyl Cellulose $2 \%$ (438.6 USD). Conclusion: This is the first of cost analysis of excipients of pediatric formulations in Saudi Arabia. Most of excipients of pediatric formulations products not registered in the famous countries. The hospital pharmacy updates annually all cost analysis of excipients pediatric formulations. The pharmacist should select the best and appropriate excipients for the formulations. The cost analysis project as part of updated the pharmacy strategic plan with new Saudi Vision 2030.

Key words: Cost, Clinical, Compounding, Excipients, Vehicles, Pediatrics,
\end{abstract}

Formulations, Ministry of Health, Saudi Arabia

\section{INTRODUCTION}

One of the primary section in the pharmacy services was an extemporaneous preparation unit. This section called non-sterile preparation or clinical compounding services and regulated by international pharmacy societies. ${ }^{[1,2]}$ Any formulations consisted of principal substance or medications and excipients. Those excipients or maybe supplements that is the need to dissolve the medications. ${ }^{[3,4]}$ Those excipients can be made in the extemporaneous section in the pharmacy or cane ready for the manufactures. There are several excipients used in the pediatrics or geriatrics formulations, for instance, diluent (methyl cellulose) and sweetener (simple syrup). ${ }^{[3,4]}$ Those products need to calculate the cost $t$ as part of the overall cost of the complete pediatric formulations of medications. Besides, the pediatrics formulation is several challenges; that's including but not limited to the differences in formulation's pharmacokinetics, drug's taste and palatability and different in formulation's stabilities. ${ }^{[5]}$ Some products had a short time of stability and sometimes the product not marketed; for instance, anti-ulcer
Ranitidine and Omeprazole syrup. ${ }^{[6]}$ The short stability lead to more frequent preparation annually and cost burden. The usage of different excipient plays role in changing the stability. Another additional burden cost on the formulations. The cost analysis excipient pediatrics formulations are the demanding of calculation the income and expenses as the privatization model. ${ }^{[7]}$ Besides, the cost analysis of the formulations as part of the pharmacoeconomic program in the pharmacy strategic plan of the Ministry of Health with new Saudi vision 2030. ${ }^{[8]}$ The authors, based on the best of their knowledge, are not familiar with any local or Gulf and Middle East countries or international publications about the cost analysis of pediatric formulations excipient. The aim of this study to explore the cost analysis of pediatric formulations excipient in the Kingdom of Saudi Arabia.

\section{METHODS}

It is a retrospective cost analysis of drug information services past one year at 300-beds pediatrics 
and maternity hospital in Riyadh city, Saudi Arabia. It had inpatient admission and ambulatory care clinics and emergency departments. The hospital had a different specialty for women adults and pediatrics. The hospital treats the common neonatal, pediatric and women's health disease. The hospital had pharmacy serve the patient including inpatient pharmacy with unit dose drug distribution system, outpatient pharmacy and extensive extemporaneous pediatrics section and drug information center. The pharmacy computerized physician order entry with an electronic prescription in addition to the pharmacy had a medication safety program. The pharmacy trained clinical and pharmacy student training programs. The extemporaneous section had very comprehensive pediatrics formulations for neonates and pediatrics in the central region of the Ministry of Health hospitals. The section received the specific formulation from physician then the expert pharmacist applied the international standard of clinical compounding through by providing to healthcare staff over eight hours per days for five days per a week. The pediatric formulations consisted of antibiotics, anti-Tuberculosis (TB) medications, anticonvulsant medications and Gastrointestinal (GI) drugs, anti-hypertension medications, electrolyte supplements, renal preparations, diuretics formulation, steroid perorations and other supportive substances formulation. The analysis of the cost included the variable expenses included personal cost, material and supply cost. Fixed costs including direct cost, non-salary cost and overhead cost. ${ }^{[9,10]}$ In addition to the cost of compounding substances, number of preparations and time of preparations. The price was derived from the Ministry of Health information database. All cost was used US dollar currency. The study analyzed antibiotics pediatric formulations through the Microsoft Excel sheet version $10^{\text {th }}$.

\section{RESULTS}

The estimated average total standard cost of pediatrics formulations per hour was (53.82 USD and consisted of $58.58 \%$ (31.53 USD) for personal cost, $25.14 \%$ (13.53 USD) for overhead cost, $3.34 \%$ (1.8 USD) for material and supply cost, $12.93 \%$ (6.96 USD) for non-salary cost (Table 1). The average estimated cost of simple syrup per each preparation was (1.974 USD) with consisted of standard cost (0.996 USD) and direct cost was (0.978 USD). The total annual cost of simple syrup was (426.38 USD) (Table 2). The average estimated cost of methyl cellulose $1 \%$ plus simple syrup per each preparation was (3.721 USD) with consisted of standard cost (0.198 USD) and direct cost was (3.523 USD). The total annual cost of methyl cellulose $1 \%$ was (759.1 USD) (Table 3 ). The average estimated cost of methyl cellulose $1 \%$ per each preparation was (2.5 USD) with consisted of standard cost (1.345 USD) and direct cost was (1.155 USD). The total annual cost of methyl cellulose $1 \%$ was (584.8 USD) (Table 4). The average estimated cost of methyl cellulose $2 \%$ per each preparation was (3.655 USD) with consisted of standard cost (1.794 USD) and direct cost was (1.861USD). The total annual cost of methyl cellulose $2 \%$ (438.6 USD) (Table 5).

\section{DISCUSSION}

In the current research site hospital pharmacy established extemporaneous unit based on the international and local standard. ${ }^{[2,11]}$ The unit consisted of appropriate equipment and materials, personnel, education and training and standardized pediatric formulations. ${ }^{[1]}$ The material needed to bring from pharmaceutical companies as a primary stock material or readymade material. For instance, simple syrup. It can be brought the auger and distill water and the pharmacist can prepare the simple syrup based on USA or UK pharmacopeia. It can be bought as the ready-made simple syrup. The choice between them depends on the cost of primary material and ready-made, the quantities needed, type of pediatrics preparation. In the current extemporaneous unit bought the primary material and prepared in the unit. After finished product, the extemporaneous unit needs to calculate the cost of foundations and selling cost. In the current study showed the cost of analysis of some excipient. The most indirect cost came from personal cost with the high demand for pharmacy staff to prepare the pediatric formulations. In the simple syrup, the cost of direct and indirect cost almost equal that has related few of the preparations and extended time for preparations. There is not simple syrup registered in the local and international market to compare the cost with it (Table 6). ${ }^{[12-15]}$ In the universal vehicle, the direct cost more than the indirect cost that is related to the high cost of raw materials. There is not a universal vehicle registered in Saudi Arabia or the UK and the USA to compare the cost with it (Table 6). ${ }^{[12-15]}$ The methylcellulose oral liquid or solution with different concentration is not registered in the KSA, USA and UK countries. The direct and indirect, almost equal, that is related long time and few numbers of preparations. The costliest consumed from extemporaneous preparation was a universal vehicle and methyl cellulose that's related expenditures of material. All previous excipients not registered at famous countries and local setting. All the product should continue to prepare them for pediatric formulations (Table 6). ${ }^{[12-15]}$
Table 1: Standard cost analysis of pediatrics formulations (USD).

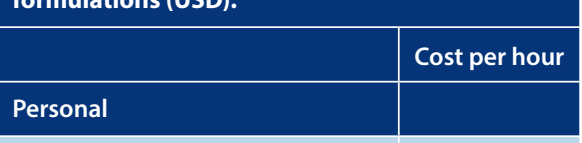

Head compounding pharmacist

27.27

staff compounding pharmacist

4.26

Total

31.53

Over Head cost

Rent

0

Bed

0

Offices

0.46

Chairs

1.54

Computer

0.68

Printer

1.43

Zebra label printer (Direct Thermal)

3.08

Refrigerator

1.66

Balance

0.17

Beakers

0.14

Stainless steel spoon

0.21

Measuring cup

0.25

Measuring Cylinder

0.15

Silicone spoon

0.05

cooker

0.03

Funnel

0.04

Bunchner

0.05

Test tube brush

0.04

Kettle

0.15

Mortar and Pestle

0.11

Glass rode

0.02

Shelf

3.23

Pen/pencils

0.04

scissors

0.02

Total

Material and supply

Large

0.65

Amber bottle

0.21

Syringe

0.12

gloves

0.49

Blue sheet

0.31

Face mask

0.02

Total

1.8

Non Salary cost

Education and Training head

Education and Training staff

Total 6.96 
Table 2: Cost of Simple Syrup NF (USD).

Personal

31.53

Over Head cost

13.53

Material and supply

1.8

Non Salary cost

Total

Preparation time $4 \mathrm{hr}$ per one bottle

Total of preparation 216 per year, the cost per one $333 \mathrm{ml}$ 6.96

53.82

215.28

Direct cost

Sucrose granules $=667$ GM

0.889

Distill Water to $333 \mathrm{ml}$

0.089

Total

Grand Total $333 \mathrm{ml}$ per bottle

0.978

1.974

Annual Grand Total cost

426.38

References

1. DeRamus A. Syrup NF. International Journal of Pharmaceutical Compounding. 1997;1(2):111

\section{Table 3: Cost of Methylcellulose 1\% oral liquid vehicles (USD).}

\begin{tabular}{|l|c|}
\hline Personal & 31.53 \\
\hline Over Head cost & 13.53 \\
\hline Material and supply & 1.8 \\
\hline Non Salary cost & 6.96 \\
\hline Total & 53.82 \\
\hline Preparation time 45 min per one bottle & 40.365 \\
\hline Total of preparation 204 per year, the cost per one 400 ml & 0.198 \\
\hline Direct cost & \\
\hline MethylCellulose1\%= 280 ml & 0.323 \\
\hline Simple syrup to 400 ml & 3.200 \\
\hline Total & 3.523 \\
\hline Grand Total 100 ml per bottle & 3.721 \\
\hline Annual Grand Total cost & 759.1 \\
\hline References & \\
\hline 1. DeRamus A. Methylcellulose Oral Liquid Vehicles. International Journal of \\
\hline$\quad$ Pharmaceutical Compounding.1997;1(2):105
\end{tabular}

\section{Table 4: Cost of Methylcellulose 1\% Solution (USD).}

Personal

31.53

Over Head cost

13.53

Material and supply

1.8

Non Salary cost

Total

6.96

53.82

Preparation time $4 \mathrm{hr}$ per one bottle

215.28

Total of preparation 160 per year, the cost per one $1000 \mathrm{ml}$

1.345

Direct cost

Methyl Cellulose $=10 \mathrm{GM}$

0.707

Sodium Benzoate $=2$ GM

0.181

Distill Water to $1000 \mathrm{ml}$

0.267

Total

1.155

Grand Total $100 \mathrm{ml}$ per bottle

Annual Grand Total cost

584.8

\section{References}

1. M. Haq ABS, Mohd Din RB, Othman NB, et al. Extemporaneous Formulation. Pharmaceutical Services Division. Ministry of Health Malaysia. 2015

\section{Table 5: Cost of Methylcellulose $2 \%$ Solution (USD).}

Personal

31.53

Over Head cost

13.53

Material and supply

1.8

Non Salary cost

6.96

Total

53.82

Preparation time $4 \mathrm{hr}$ per one bottle

215.28

Total of preparation 120 per year, the cost per one $1000 \mathrm{ml}$

Direct cost

Methyl Cellulose $=20$ GM

1.413

Sodium Benzoate $=2$ GM

0.181

Distill Water to $1000 \mathrm{ml}$

0.267

Total

1.861

Grand Total $100 \mathrm{ml}$ per bottle

3.655

Annual Grand Total cost

438.6

\section{References}

1. M. Haq ABS, Mohd Din RB, Othman NB, et al. Extemporaneous Formulation. Pharmaceutical Services Division. Ministry of Health Malaysia. 2015
The cost foundations of necessary supplement pediatrics formulations are essential to calculate the cost of the final extemporaneous product.

\section{CONCLUSION}

The excipients of the extemporaneous preparation for pediatrics formulation are essential in pharmacy practice. Most of the excipients ready used and their prices are not available in the international or local market. The cost analysis of excipients is a primary part of the product cost calculation. The continuous preparation of excipients with cost determination for pediatric formulation is critical and fundamental elements in the extemporaneous unit in the pharmacy practice. Besides, to implement the pharmacy strategic plan with new Saudi vision 2030 in practice.

\section{ACKNOWLEDGEMENT}

None.

\section{CONFLICT OF INTEREST}

The authors declare that there are no conflicts of interest. 


\begin{tabular}{|c|c|c|c|c|c|c|c|c|}
\hline \multirow[t]{2}{*}{ Medications name } & \multicolumn{2}{|c|}{ Cost Current study } & \multicolumn{2}{|c|}{ Cost in SA (USD) ${ }^{[12]}$} & \multicolumn{2}{|c|}{ Cost in US (USD) ${ }^{[13]}$} & \multicolumn{2}{|c|}{ Cost in UK (USD) ${ }^{[14,15]}$} \\
\hline & Conc. $\mathrm{mg} / \mathrm{ml}$ & Volume & $\begin{array}{l}\text { Conc. } \\
\mathrm{mg} / \mathrm{ml}\end{array}$ & Volume & $\begin{array}{l}\text { Conc. } \\
\mathrm{mg} / \mathrm{ml}\end{array}$ & Volume & $\begin{array}{l}\text { Conc. } \\
\mathrm{mg} / \mathrm{ml}\end{array}$ & Volume \\
\hline Simple Syrup NF & $\mathrm{ml}=0.00592 \$$ & $\begin{array}{c}333 \mathrm{ml}=1.974 \$ \\
(100 \mathrm{ml}=0.592 \%)\end{array}$ & $\begin{array}{l}\text { Simple } \\
\text { Syrup }\end{array}$ & $\begin{array}{l}\text { Simple } \\
\text { Syrup }\end{array}$ & $\begin{array}{c}\text { Not } \\
\text { available }\end{array}$ & $\begin{array}{c}\text { Not } \\
\text { available }\end{array}$ & $\begin{array}{c}\text { Non } \\
\text { available }\end{array}$ & $\begin{array}{c}\text { Non } \\
\text { available }\end{array}$ \\
\hline $\begin{array}{c}\text { Methylcellulose } 1 \% \text { oral } \\
\text { liquid vehicles }\end{array}$ & $\mathrm{ml}=0.0093 \$$ & $\begin{array}{c}400 \mathrm{ml}=3.721 \$ \\
(100 \mathrm{ml}=0.93)\end{array}$ & $\begin{array}{c}\text { Not } \\
\text { available }\end{array}$ & $\begin{array}{c}\text { Not } \\
\text { available }\end{array}$ & $\begin{array}{c}\text { Not } \\
\text { available }\end{array}$ & $\begin{array}{c}\text { Not } \\
\text { available }\end{array}$ & $\begin{array}{c}\text { Non } \\
\text { available }\end{array}$ & $\begin{array}{c}\text { Non } \\
\text { available }\end{array}$ \\
\hline $\begin{array}{l}\text { Methylcellulose } 1 \% \\
\text { Solution }\end{array}$ & $\mathrm{ml}=0.00267 \$$ & $\begin{array}{c}1000 \mathrm{ml}=0.267 \$ \\
(100 \mathrm{ml}=0.0 .0267)\end{array}$ & $\begin{array}{c}\text { Not } \\
\text { available }\end{array}$ & $\begin{array}{c}\text { Not } \\
\text { available }\end{array}$ & $\begin{array}{c}\text { Not } \\
\text { available }\end{array}$ & $\begin{array}{c}\text { Not } \\
\text { available }\end{array}$ & $\begin{array}{c}\text { Non } \\
\text { available }\end{array}$ & $\begin{array}{c}\text { Non } \\
\text { available }\end{array}$ \\
\hline $\begin{array}{l}\text { Methylcellulose } 2 \% \\
\text { Solution }\end{array}$ & $\mathrm{ml}=0.003655 \$$ & $\begin{array}{c}1000 \mathrm{ml}=3.655 \$ \\
(100 \mathrm{ml}=0.3655)\end{array}$ & $\begin{array}{c}\text { Not } \\
\text { available }\end{array}$ & $\begin{array}{c}\text { Not } \\
\text { available }\end{array}$ & $\begin{array}{c}\text { Not } \\
\text { available }\end{array}$ & $\begin{array}{c}\text { Not } \\
\text { available }\end{array}$ & $\begin{array}{c}\text { Non } \\
\text { available }\end{array}$ & $\begin{array}{c}\text { Non } \\
\text { available }\end{array}$ \\
\hline
\end{tabular}

\section{ABBREVIATIONS}

SFDA: Saudi Food and Drug Authority; KSA: Kingdom of Saudi Arabia; USD: United State Dollars; GI: gastrointestinal; GERD: Gastroesophageal reflex diseases, MOH: Ministry of Health; TB: tuberculosis; USA: United States of America; UK: United Kingdom.

\section{ORCID ID}

Yousef Ahmed Alomi (iD) https://orcid. org/0000-0003-1381-628X

\section{REFERENCES}

1. Kienle PC. Compounding nonsterile preparations: USP <795> and <800>. Pharm Today. 2017;23(10):56-72

2. USP. USP General Chapter < 795> Pharmaceutical Compounding - Nonsterile Preparations. In: USP 42-NF. 2019;1-13. Available from: http://www.usp. org/compounding/general-chapter-795.

3. Riet-Nales DAV, Kozarewicz P, Aylward B, DeVries R, Egberts TCG, Rademaker CMA, et al. Paediatric Drug Development and Formulation DesignEuropean Perspective. AAPS Pharm Sci Tech. 2017; 18(2):241-9.

4. Chatterjee P, Yochana S, Yu M, Alvi M, Varenya S Pharmaceutical excipients and pediatric formulations. Chim Oggi/Chemistry Today. 2012;30(5):5661.

5. Batchelor HK, Marriott JF. Formulations for children: Problems and solutions. Br J Clin Pharmacol. 2015;79(3):405-18.

6. Glass BD, Haywood A. Stability considerations in liquid dosage forms extemporaneously prepred from crmecially avilble products. J Pharm Pharm Sci. 2016;9(3):398-426

7. Alomi YA. New pharmacy model for vision 2030 in Saudi Arabia. J Pharm Pract Community Med. 2017;3(3):194-6.

8. Alomi YA, Alghamdi SJ, Alattyh RA, Elshenawy RA. The Evaluation of Pharmacy Strategic Plan in Past 2013-2016 and Forecasting of New Vision 2030 at Ministry of Health in Saudi Arabia. J Pharm Pract Community Med. 2018;4(2):93-101.
9. Alomi YA, Al-Jarallah SM. The cost analysis of network drug information services at ministry of health institutions in Saudi Arabia. J Pharm Pract Community Med. 2018;4(4):226-30.

10. Alomi YA, Alsulami N, Al-Qahtani N, Mashouf M, Qahtani A, Almansor FA. Cost analysis of drug information services at the mental hospital in Saudi Arabia. J Pharm Pract Community Med 2018;4(2):83-6.

11. Carroll NV, Brusilovsky I, York B, Oscar R. Comparison of costs of community and mail service pharmacy. J Am Pharm Assoc. 2005;45(3):336-43

12. Saudi Food and Drug Authority. List of human medicine and herbal health. 2019. Cited 2019 Jun 17. Available from: https://www.sfda.gov.sa/en/ drug/resources/Pages/DrugsUnderRegistrations. aspx.

13. Athenahealth. Epocrates Online. Epocrates.com. 2017. Cited 2019 Jun 17. Available from: https:// online.epocrates.com/home.

14. Ah-See KW. Royal Pharmaceutical Society. British National Formulary 76. British National Formulary - BMJ Group. 2019;1-1653.

15. British Medical Association. BNF for Children 2017-2018. 2017. 